\title{
Anthelmintic and diuretic activity of bark extracts of Sterculia villosa
}

\author{
Md. Rashedul Alam ${ }^{1}$, Md. Raton ${ }^{2}$, Md. Musfizur Hassan ${ }^{3}$, Mohammad Fahim Kadir ${ }^{4}$, S.M. Ashraful Islam ${ }^{4}$ and Md. \\ Ahsanul Haque ${ }^{4} *$ \\ ${ }^{1}$ Departmenty of Pharmaceutical Technology, University of Dhaka, Dhaka, Bangladesh. \\ ${ }^{2}$ Department of Pharmaceutical Chemistry, University of Dhaka, Dhaka, Bangladesh. \\ ${ }^{3}$ Department of Pharmacy, Jahangirnagar University, Savar, Dhaka, Bangladesh. \\ ${ }^{4}$ Department of Pharmacy, University of Asia Pacific, Dhaka, Bangladesh.
}

\section{ARTICLE INFO}

Article history:

Received on: 01/10/2012

Revised on: 13/10/2012

Accepted on:18/10/2012

Available online: 28/10/2012

Key words: Sterculia villosa, Diuretic activity, Anthelmintic activity, Furosemide,

Albendazole.

\begin{abstract}
The study was evaluated for diuretic and anthelmintic activity of the ethanolic extract of the barks of Sterculia villosa Roxb, (Sterculiaceae). The diuretic assay was done on both healthy wistar rats and rabbits. The dose used for the diuretic assay was $100,200 \& 400 \mathrm{mg} / \mathrm{kg}$ of the extract. Compared to the control and standard drug furosemide $(20 \mathrm{mg} / \mathrm{kg})$, the result of diuretic study showed dose dependent activity of the extracts. The result also indicated higher excretion of $\mathrm{Na}^{+}, \mathrm{K}^{+} \& \mathrm{Cl}^{-}$in urine. Pheretima posthuma, adult earthworms were used for anthelmintic activity and the results of anthelmintic assessment at the dose of 50, $100 \& 200 \mathrm{mg} / \mathrm{ml}$ showed significant activity compared with control and standard drug albendazole $(10 \mathrm{mg} / \mathrm{ml})$
\end{abstract}

\section{INTRODUCTION}

Sterculia villosa Roxb, (Sterculiaceae) are deciduous tree with grey or brown bark covered with corky nodules commonly known as 'Udal' or 'Udar'. It is one of the fast-growing plant species, has large long-stalked deeply lobed leaves and yellow flowers (Joshi, 2011). It is distributed More or less throughout North Eastern region of India, Bangladesh, Sri Lanka, Southern China (Ghani, 2003). Some chemical constituents like flavonoids, chrysoeriol, diosmetin-7-O- $\beta$-D-glucoside and chrysoeriol-7-O- $\beta$-D-glucoside were isolated from $S$. villosa (Seetharaman, 1990).

* Corresponding Author

Md. Ahsanul Haque

Department of Pharmacy, University of Asia Pacific, House \# 73,

Road \# 5A, Dhanmondi R/A, Dhaka-1209, Bangladesh.

Mobile: 0088-01676103245, Telephone: (880-2) 9664953

Fax: (880-2) 96649
The plant is used by Indians for traditional remedy of Inflammation (Namsa et al., 2009). The plant also has antioxidant activity (Kshirsagar and Upadhyay, 2009). Traditionally, the plant is used in diuretic, cooling and aphrodisiac properties (Kumar et al., 2004). Our study was designed to rationalize the traditional use of $S$. villosa by evaluating the diuretic effects on healthy rats and rabbits. Generally, diuretics are the compounds which promote the flow of urine in larger amounts than the normal. The diuretics are particularly useful in the treatment of ascites, congestive cardiac failure, and edema of the lungs, kidneys and liver. In these conditions fluid abnormally accumulates in the body. Diuretics increase the excretion of $\mathrm{Na}^{+}$which may induce antihypertensive effect. Such compounds may act on nephron in the kidney leading to a decrease in the re-absorption of water and subsequently increased urine output (Singh and Dixit, 1992). 
They are commonly used for management of hypertension and electrolytic balance. So, the present study assesses the diuretic effects of the ethanolic extract of S. villosa barks.

Parasitic diseases cause ruthless morbidity affecting principally population in endemic areas (Dhanvantari et al., 1989). Helminthiasis is a macroparasitic disease of humans and animals in which a part of the body is infested with parasitic worms such as pinworm, roundworm, or tapeworm. Anthelmintic drugs are used to destroy or cause the expulsion of such parasitic intestinal worms and helps to treat helminthiasis, one of the most common infections in humans and cattle. Albendazole is the first drug of choice for the treatment of worm infections. The gastro-intestinal helminthes becomes resistant to currently available anthelmintic drugs therefore there is a foremost problem in treatment of helminthes diseases (Sondhi et al., 1994). Hence there is an increasing demand towards natural anthelmintics. To overcome the resistance, plant derived drugs can serve as prototype to develop more effective and less toxic medicines (Rastogi et al., 2009). The modern system of medicine claims that plants can be the cheapest source of treatment and can be safely used only after safety evaluation and dose determination for its effective use. Once the safety of plant and its dose dependent effectiveness is determined, plants can serve humans to treat and heal almost all the ailments. However, increasing problems of development of resistance in helminthes (Dorny et al., 1995) have led to the proposal of screening medicinal plants for their anthelmintic activity. The purpose of this study was to evaluate ethanolic extract of $S$. villosa barks as new potential sources of natural anthelmintic.

\section{MATERIALS AND METHODS}

\section{Plant material}

Sterculia villosa Roxb, (Sterculiaceae) fresh bark collected from Rangamati, Bangladesh in sepetember 2011 were authenticated by the taxonomist Dr. Jasim Uddin, Associate Professor, Department of Botany, University of Dhaka and the identification number was documented as Accession no DUSH 6905 and Call no 01.

\section{Preparation of extracts}

The barks of Sterculia villosa washed with distilled water to remove dirt and soil. Then the barks were cut into small pieces and then dried. The dried materials were powdered and passed through a 10-mesh sieve. The coarsely powdered material was extracted thrice with ethanol. The extracts were filtered, pooled and concentrated under reduced temperature on a rotary evaporator. The extract was stored in a refrigerator and used for the present study.

\section{Drugs and chemicals used}

All chemicals and drugs were obtained commercially and were of analytical grade. Albendazole was collected from Beximco Pharmaceuticals Ltd., Bangladesh. DMF (Merck, Germany) was used.

\section{Test animals: Earthworms}

Adult earthworms (Pheretima posthuma) were collected from moist soil of Savar area of Dhaka in Bangladesh and washed with normal saline to remove all fecal matters. Then the worms were used for anthelmintic study. The earthworms of $8-10 \mathrm{~cm}$ in lengths and $0.3-0.5 \mathrm{~cm}$ in width were used for all the experimental protocol.

\section{Test animals: Rats}

Albino (Wistar) rats 150-200 gm of either sex were used for the study. The animals were kept in the standard polypropylene cages and provided with food and water ad libitum. The animals were housed under standard environmental conditions with controlled conditions of temperature $\left(23 \pm 2{ }^{\circ} \mathrm{C}\right)$, humidity $(50 \pm 5$ $\%)$ and 12 hours light-dark cycles. The animals were acclimatized for a period of 14 days prior to perform the pharmacological experiments.

\section{Test animals: Rabbits}

The study was conducted on 25 healthy rabbits of either sex weighing between 2.5 to $3.5 \mathrm{~kg}$. Animals were housed in separate cages under controlled conditions of temperature $(23 \pm$ $2{ }^{\circ} \mathrm{C}$ ) and humidity $(50 \pm 5 \%)$. All animals were given green leafy diet and water regularly. The experiments were performed according to the current guidelines for the care of the laboratory animals.

\section{Assessment of anthelmintic activity}

The anthelmintic activity was evaluated on adult earthworm Pheritima posthuma (Ajaiyeoba et al., 2001; Deore et al., 2009). All worms were divided into five groups (Six worms in each group) and used to assess the anthelmintic properties of ethanolic extracts of $S$. villosa barks. Group I was the control, worms placed in normal saline and groups II, III \& IV were treated with $50,100 \& 200 \mathrm{mg} / \mathrm{ml}$ of ethanolic extracts $S$. villosa barks respectively. In order to administer these doses, the extracts were measured respectively and were dissolved in minimum amount of DMF. After proper mixing of extract and DMF, normal saline was slowly added. Group V received albendazole at the dose of $10 \mathrm{mg} / \mathrm{ml}$. It was dissolved in minimum amount of DMF and finally the volume was adjusted with normal saline. The anthelmintic assay was carried out as per the method of Ajaiyeoba et. al, 2001 with minor modifications (Ajaiyeoba et al., 2001). Observations were made for the time taken for paralysis (Paralysis was said to occur when worm did not revive in normal saline) and death. Time for death of worms was recorded after ascertaining that worms neither moved when shaken vigorously nor when dipped in warm water $\left(50{ }^{\circ} \mathrm{C}\right)$, followed with their body colors fading away.

Due to the anatomical and physiological resemblance to the human intestinal round worm parasite, the assay was performed on adult earthworm, Pheretima posthuma (Vidyarthi, 1967; Chatterjee, 1967). The individual earthworms were placed in $50 \mathrm{ml}$ of five different formulations containing normal saline, three 
different concentrations of crude ethanol extract $(50 \mathrm{mg} / \mathrm{ml}$, $100 \mathrm{mg} / \mathrm{ml}$ and $200 \mathrm{mg} / \mathrm{ml}$ in saline water) and standard Albendazole $(10 \mathrm{mg} / \mathrm{ml})$ suspension. The Time for paralysis and time for death was noted. The earthworms in control (group I) were alive up to 24 hours of the experiment.

\section{Assessment of Diuretic Activity on Rats}

Male Wistar rats weighing 150 to $180 \mathrm{gm}$ were maintained under standard condition of temperature and humidity. The method of Lipschitz et al. (1943) and Murugesan et al., (2000) was employed for the assessment of diuretic activity. Five groups of six rats in each group were fasted and deprived of water for 18 hours prior to the experiment. All the animals received priming dose of normal saline solution of $25 \mathrm{ml}$ per $\mathrm{kg}$ body weight. First group (negative control) received $5 \mathrm{ml} / \mathrm{kg}$ of body weight of normal saline, second group (positive control) received Furosemide $(20 \mathrm{mg} / \mathrm{kg}$ ) and the third, fourth \& fifth groups received the ethanolic extract in normal saline at the doses of 100 , $200 \& 400 \mathrm{mg} / \mathrm{Kg}$ respectively. Immediately after administration, the rats (one in each cage) were placed in metabolic cages specially designed to separate urine and feces and kept at room temperature of $25 \pm 0.5^{\circ} \mathrm{C}$ throughout the experiment. The urine was collected in measuring cylinders up to $5 \mathrm{hrs}$ after dosing. During this period, no food or water was made available to animals. The parameters taken for each individual rat was total urine volume, concentration of $\mathrm{Na}^{+}, \mathrm{K}^{+} \& \mathrm{Cl}^{-}$in urine. $\mathrm{Na}^{+}, \mathrm{K}^{+}$ concentrations were measured by Flame photometry (Jeffery et al., 1989) and $\mathrm{Cl}^{-}$concentration was estimated by titration (Beckette and Stenlake, 1997) with silver nitrate solution(N/50)using three drop of $5 \%$ potassium chromate solution as indicator. The mean urine volumes were determined and diuretic potency was assessed by comparison of urine excretion due to the extracts with respect to the standard drug furosemide.

\section{Assessment of Diuretic Activity on Rabbits}

We also took Male white rabbits that were again divided into five groups for the same test. Normal saline, furosemide and ethanolic extract $(100 \mathrm{mg} / \mathrm{kg}, \quad 200 \mathrm{mg} / \mathrm{kg}, \quad 400 \mathrm{mg} / \mathrm{kg})$ are administered in the same way as in male rat. After 20 minutes the rabbits were intravenously anaesthetized with $3 \%(\mathrm{w} / \mathrm{v})$ sodium pentobarbital solution at $30 \mathrm{mg} / \mathrm{kg}$ body weight. Sterile liquid paraffin was used to lubricate the catheter that was inserted in the bladder to discharge urine from all groups after a brief period of fasting.
Again physiological saline $(0.9 \% \mathrm{NaCl})$ was supplied to the animals at a speed of $2 \mathrm{ml} / \mathrm{min}$ by ear vein injection at $10 \mathrm{ml} / \mathrm{kg}$ body weight. Catheter was used to collect the urine that was measured up to 4 hours of treatment (Xu et al., 2002).

\section{Statistical Analysis}

The results are expressed as Mean values \pm S.E.M. (standard error of mean). Statistical comparison was carried out by analysis of variance (ANOVA). The difference between the means of treated groups and the non-treated control group was evaluated by the Bonferroni Multiple Comparisons. The results were considered statistically significant when $\mathrm{P}<0.05$.

\section{RESULTS AND DISCUSSION}

\section{Anthelmintic Activity}

In this anthelmintic assay, extract of $S$. villosa barks demonstrated paralysis as well as death of worms. As shown in Table 1, ethanolic extract exhibited anthelmintic activity in dosedependent manner giving shortest time of paralysis and death with $200 \mathrm{mg} / \mathrm{ml}$ concentration. Higher concentration of extract produced paralytic effect much earlier and the time to death was shorter for all worms. Evaluation of anthelmintic activity was compared with reference standard drug Albendazole.

The ethanolic extract of Sterculia villosa barks were found to be effective upon comparison with the Standard drug albendazole in causing paralysis and death of earthworms. It can be concluded that active constituents responsible for anthelmintic activity might be present in the bark extracts.

Table 1: Anthelmintic activity of ethanolic extracts of $S$. villosa barks.

\begin{tabular}{|c|c|c|c|c|}
\hline $\begin{array}{l}\text { Sl } \\
\text { No. }\end{array}$ & Test Group & $\begin{array}{c}\text { Concentration } \\
(\mathrm{mg} / \mathrm{ml})\end{array}$ & $\begin{array}{c}\text { Time taken } \\
\text { for paralysis } \\
(\mathrm{min})\end{array}$ & $\begin{array}{l}\text { Time taken } \\
\text { for death } \\
(\text { min })\end{array}$ \\
\hline 1 & Control & - & - & - \\
\hline 2 & $\begin{array}{l}\text { Ethanol } \\
\text { Extracts }\end{array}$ & 50 & $69.24 \pm 1.75$ & $81.42 \pm 2.08$ \\
\hline 3 & $\begin{array}{l}\text { Ethanol } \\
\text { Extracts }\end{array}$ & 100 & $63.51 \pm 1.79$ & $76.58 \pm 2.35$ \\
\hline 4 & $\begin{array}{l}\text { Ethanol } \\
\text { Extracts }\end{array}$ & 200 & $54.38 \pm 2.39$ & $69.39 \pm 3.27$ \\
\hline 5 & Albendazole & 10 & $26.43 \pm 1.94$ & $43.64 \pm 2.13$ \\
\hline
\end{tabular}

All values represent Mean \pm SE; $\mathrm{p}<0.05$.

\section{Diuretic Activity in Rats}

The present study revealed that, ethanolic extract of $S$. villosa barks significantly increased the urinary output as well as urinary electrolyte concentration in normal rats.

Table 2: Diuretic activity of $S$. villosa barks in rats.

\begin{tabular}{|c|c|c|c|c|c|c|c|c|c|}
\hline \multirow{2}{*}{ Treatment } & \multirow{2}{*}{$\begin{array}{c}\text { Dose } \\
(\mathrm{mg} / \mathrm{kg})\end{array}$} & \multirow{2}{*}{$\begin{array}{c}\text { Urine } \\
\text { Volume (ml) }\end{array}$} & \multicolumn{3}{|c|}{ Electrolyte Excretion } & \multirow{2}{*}{$\begin{array}{c}\mathrm{Na}+/ \mathbf{K}+ \\
\text { ratio }\end{array}$} & \multirow{2}{*}{$\begin{array}{c}\text { Diuretic } \\
\text { index }\end{array}$} & \multirow{2}{*}{$\begin{array}{l}\text { Lipschitz } \\
\text { value }\end{array}$} & \multirow{2}{*}{$\begin{array}{c}\% \\
\text { Increase } \\
\text { in Urine }\end{array}$} \\
\hline & & & $\begin{array}{c}\mathrm{Na}+ \\
(\mathrm{mEq} / \mathrm{L})\end{array}$ & $\mathbf{K}+(\mathbf{m E q} / \mathbf{L})$ & $\begin{array}{c}\mathrm{Cl}- \\
(\mathrm{mEq} / \mathrm{L})\end{array}$ & & & & \\
\hline Control & $25 \mathrm{ml} / \mathrm{kg}$ & $4.391 \pm 0.078$ & $90.8+0.77$ & $51.64+2.18$ & $96.85+1.12$ & 1.78 & - & - & \\
\hline Furosemide & 20 & $10.278+0.095$ & $138.4+1.78$ & $95.75+1.39$ & $159.61+1.10$ & 1.44 & 2.34 & - & 100 \\
\hline Ethanolic Extract & 100 & $6.158+0.089$ & $101.5+1.47$ & $69.15+1.17$ & $119.44+1.46$ & 1.47 & 1.40 & 0.60 & 59.91 \\
\hline Ethanolic Extract & 200 & $6.822+0.092$ & $112.2+1.36$ & $74.26+1.12$ & $125.58+1.31$ & 1.51 & 1.58 & 0.66 & 66.37 \\
\hline Ethanolic Extract & 400 & $8.178+0.109$ & $121.9+1.37$ & $86.38+1.21$ & $141.37+1.38$ & 1.41 & 1.55 & 0.79 & 79.56 \\
\hline
\end{tabular}

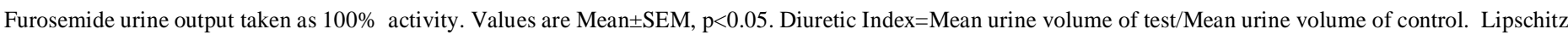
value $=$ Mean urine volume of test/Mean urine volume of standard . 
Table 3: Diuretic Activity of S. villosa barks in Rabbits.

\begin{tabular}{lccc}
\hline Treatment & Dose $(\mathbf{m g} / \mathbf{k g})$ & $\begin{array}{c}\text { Urine } \\
\text { Volume }(\mathbf{m l})\end{array}$ & $\begin{array}{c}\text { \% Increase in } \\
\text { Urine }\end{array}$ \\
\hline Control & Normal Saline & $19.49 \pm 0.34$ & - \\
Furosemide & 20 & $58.68+0.51$ & 100 \\
Ethanolic Extract & 100 & $29.51+0.59$ & 50.28 \\
Ethanolic Extract & 200 & $35.82+0.72$ & 61.04 \\
Ethanolic Extract & 400 & $43.67+0.69$ & 74.42 \\
\hline
\end{tabular}

Furosemide urine output taken as $100 \%$ activity. Values are Mean \pm SEM, $\mathrm{p}<0.05$.

Urine output of ethanolic extracts treated animals was more than saline treated animals. However the urine output of treated animals was less than standard drug treated animals. Maximum urine output was obtained at the dose of $400 \mathrm{mg} / \mathrm{kg}$ of ethanolic extract treated animals. Maximum Sodium, Potassium \& chloride concentration was also observed in $400 \mathrm{mg} / \mathrm{kg}$ dosed ethanolic extract treated animals. These features suggest that the plant extract is acting in a similar way as furosemide, which increases urinary output and urinary excretion of sodium by inhibiting $\mathrm{Na}+/ \mathrm{K}+/ \mathrm{Cl}$ - transporter system in the thick ascending loop of Henley (Jackson, 1996).

\section{Diuretic Activity in Rabbits}

Diuretic effects of ethanolic extracts of $S$. villosa barks on male rabbits are shown in table-3. The result of diuretic activity of the present study showed that the ethanolic extract of $S$. villosa barks at 100, 200 and $400 \mathrm{mg} / \mathrm{kg}$ caused a dose dependent increase of urinary water in rabbits. The results of $400 \mathrm{mg} / \mathrm{kg}$ treated group showed maximum diuretic effects and urine volume $(\mathrm{P} \leq 0.01)$ compared with control group.

\section{CONCLUSION}

From the results of the present study, it is concluded that S. villosa showed significant anthelmintic activity. The plant may be further explored for its phytochemical profile to recognize the active constituent responsible for anthelmintic activity. As diuretics lessen pulmonary congestion and peripheral edema, these agents are useful in reducing the syndrome of volume overload, including orthopnea and paroxysmal nocturnal dyspnoea. They increase plasma volume and subsequently venous return to the heart. This decreases cardiac work load, oxygen demand and plasma volume, thus decreasing blood pressure. Thus diuretics play an important role in hypertensive patients. On the basis of the results of the present investigations, we can conclude that the ethanolic extracts of $S$. villosa. barks found to produce significant diuretic activity, in a dose dependent manner up to 5 hours of drug administration by increasing the total urine output and increased excretion of sodium and potassium salts in male wistar rats. It also showed similar diuretic activity in healthy rabbits.

Hence, further isolation of active components will be advantageous to identify novel bioactive compounds from the extracts which may possess more significant activity.

Conflict of interest: The authors declare no conflict of interest.

\section{REFERRENCES}

Ajaiyeoba E.O., Onocha P.A., Olarenwaju O.T., In vitro anthelmintic properties of Buchholzia coriaceae and Gynandropsis gynandra extract. Pharm. Biol. 2001; 39:217-220.

Ajaiyeoba, E.O., Onocha, P., Olarenwaje O.T., In vitro anthelmintic properties of Buchholzia coriaceae and Gynandropis gynanadra extract. Pharmaceutical Biol. 2001; 39(3), 217-220.

Anonymous. Dhanvantari, Vanaushadhi Visheshank (Hindi), ed. K.P. Trivedi, Dhanvantari Karyalaya, Vijaygarh, 1989; 4:PP.215.

Beckette, A.H., Stenlake, J.B., Practical Pharmaceutical Chemistry ,Part I, 1st edition ,CBS Publishers and Distributors, New Delhi 1997, 197.

Chatterjee KD. Parasitology, Protozoology and Helminthology. 6th ed. Calcutta: In Guha Ray Sree Saraswaty Press Ltd; 1967.

Deore S.L., Khadabadi S.S., Kamdi K.S., In vitro Anthelmintic activity of Cassia tora. Int. J. ChemTech Res. 2009; 1(2):177-179.

Dorny, P., Symoens, C., Jalila, A., Vercruysse, J., Sani, R., Strongyle infections in sheep and goats under the traditional husbandry system in peninsular Malaysia. Vet. Parasitol. 1995; 56: 121-136.

Ghani A. Sterculia villosa. Medicinal plant of Bangladesh: Dhaka; Asiatic society of Bangladesh; 2003.

Jackson E.K., Drugs affecting renal and cardiovascular function. In: J.C. Hardman, A.G. Gilman, L.E. Limbird, (Eds.), Goodman and Gilman's The Pharmacological Basis of Theraputics, 9th ed. Pergmon press, New York, 1996.

Jeffery, G.H., Bassett, J., Mendham, J and Denny.Vogel's Textbook of Quantitative Chemical Analysis, 5 th edition. Addison Westley Longman Ltd., England 1989, 801.

Joshi H. Sterculia villosa [Internet]. May 1999. [Cited- 14 December 2011] http://ecocrop.fao.org/ecocrop/srv/en/about

Kshirsagar R., Upadhyay S., Free radical scavenging activity screening of medicinal plants from Tripura, Northeast India. Natural Product Radiance, 2009; 8 (2): 117-122.

Kumar R., Suman N.R., Dash S.S., Traditional uses of plants by tribals of Amarakantak region, Madhya Pradesh. Indian Journal of Traditional Knowledge. 2004; 3 (4), 383-390.

Lipschitz W.L, Haddian Z. and Kerpscar A., Bioassay of diuretics, J. Pharmcol. Exp. Ther, 79, 1943, 97-110.

Murugesan T., Manikandan L., Suresh K.B., Pal M., Saha B.P., Evaluation of Diuretic potential of Jussiaea suffruticosa Linn. extract in rats, Indian J. Pharm. Sci, 2000; 62(2):150-151

Namsa N.D., Tag H., Mandal M., Kalita P., Das A.K., An ethnobotanical study of traditional anti-inflammatory plants used by the Lohit community of Arunachal Pradesh, India. Journal of Ethnopharmacology. 2009; 125 (2): 234-245

Rastogi T., Bhutda V., Moon K., Aswar P.B., Khadabadi S.S., Comparative Studies on Anthelmintic Activity of Moringa Oleifera and Vitex Negundo. Asian J. Research Chem. 2009; 2(2): 181-182.

Seetharaman T.R., Flavonoids of Firmiana simplex and Sterculia villosa. Fitoterapia. 1990; 61(4): 373-374

Singh, G.K., Dixit, V.K., Diuretic and anti-inflammatory activity of Trianthema portulacastrum Linn. Indian Drugs. 1992; 30 (4): 170-172.

Sondhi SM., Shahu R., Magan Archana. Indian Drugs 1994; 31(7): 317-320.

Vidyarthi R.D., A Text Book of Zoology. 14th ed. New Delhi: S. Chand and Co; 1967.

Xu S., Bian R., Chen X., Experimental Methodology of Pharmacology. 3rd Ver. Peoples' Medical Publishing House, Beijing. 2002; pp. 911-914, 929-930, 1224.

\section{How to cite this article:}

Md. Rashedul Alam, Md. Raton, Md. Musfizur Hassan, Mohammad Fahim Kadir, S.M. Ashraful Islam and Md. Ahsanul Haque. Anthelmintic and diuretic activity of bark extracts of Sterculia villosa. J App Pharm Sci. 2012; 2 (10): 086-089. 